\title{
Agitation for Social Justice and Moral Reform in Yeast and Alton Locke: Dialectical Interplay Between Rigid Attitudes and Humanistic Approach
}

\author{
Taher Badinjki \\ Department of English, Al-Zaytoonah University, Amman 11732, Jordan \\ E-mail: tbadinjki@hotmail.com
}

Received: 05-01-2016

Published: 01-07-2016
Accepted: 23-03-2016

doi:10.7575/aiac.ijalel.v.5n.4p.1
Advance Access Published: May 2016

URL: http://dx.doi.org/10.7575/aiac.ijalel.v.5n.4p.1

\begin{abstract}
In his attempt to bring about social reform of the appalling conditions of the working class, Charles Kingsley turned his fictional works into serious instruments of social justice and platforms to spread his views to the public. He envisioned his novels, as opportunities for readers to see with new eyes the possibilities of cooperation between classes, and called for a change of heart and for the prevailing of fellow-feeling and human brotherhood. The shadowy and degraded figures of Alton Locke and Yeast, are shown as victims of the prevailing social class division and morally irresponsible industrial relationships. Kingsley draws attention to their miserable conditions but does not delve deep into their problems. He makes touching pictorial description of their miserable conditions for the sake of raising his readers' pity, and he uses them as instruments of bringing about social reform.
\end{abstract}

Keywords: Kingsley, fiction, art, social justice, moral reform, Yeast, Alton Locke

\section{Introduction}

Charles Kingsley used his novels as a platform to reach the largest possible sector of the public, and turned them into serious tools of reform. He was deeply concerned about the appalling conditions of the working class and the condition of women, and called for the necessity of social justice and moral reform. He was a firm advocate of the education of women and the need for reforming societal abuses. In his agitation for social reform of the working class, he aimed to heal divisions, reform, and improve the role of women in society. He sought to condemn their exploitation by irresponsible men and was determined that women should be more than simply 'angels in the house.' He envisioned his novels, as opportunities for readers from the higher classes to see their fellow human beings with new eyes open to the possibilities of cooperation, and called for a change of heart and the prevailing of 'fellow-feeling'. In his letter to George Brimley, he wrote 'people are too stupid and in too great a hurry, to interpret the most puzzling facts for themselves, and the author must now and then act as showman, and do it for them' (Kingsley: 1877, 40).

Alton Locke and Yeast, focus attention on the squalor from which the poor must be raised, and on the humanity common to the rich and the poor. They draw their materials direct from existing social problems with the specific aim of awakening the reader to the need for reform. Like Dickens, Mrs Gaskell, Disraeli and others, Kingsley tried to describe the brutal realities of working class life with moving accuracy, hoping to change individual hearts as the necessary first step towards influencing society as a whole. Novels of this type were often distinguished from the bulk of Victorian fiction as "industrial" (Williams, 99), or "social problem, novels" (Kettle, 169). Whether set in "social", "industrial", or "religious" contexts, or written "for a purpose", almost all made used of different images of the poor and the depraved lost souls whose plight proved especially useful to the reforming purposes of these novels and served as a vehicle for direct social criticism. In his attempt to open people's eyes to specific social and economic evils, Kingsley made effective use of these degraded figures both in Yeast (1848), and Alton Locke (1850). Mary, the working class handsome girl, and the slop workers and needle women are shown as victims of the prevailing social class division, and morally irresponsible industrial relationships.

\section{Discussion}

Yeast, published serially in Fraser's Magazine in 1848 and in book form in 1851, is the first English novel which deals with the problem of unsanitary conditions and disease in the English countryside at the time of the Chartist agitation. It is concerned with the misery of England's agricultural workers and the problems facing them. The appalling conditions of the period between 1846 and 1847 which left many of the country poor dangerously near starvation point, and their selfish exploitation by their landlords, stimulated Kingsley to use the novel as the medium for the expression of his social ideas which he spreads as a ferment in the orthodox notions of the time and let the spirit of truth effect a solution of the problems involved. In an outline of the story which he sent to Ludlow, he wrote: "I shall be very hard on the landlords because they deserve it" (Martin, 92). 
In "A Rough Rhyme on a Rough Matter" the attack of Tregarva--the gamekeeper--on the squire sums up with splendid vigour Kingsley's diagnosis of the social diseases of rural England, and "gives some idea of the sexual squalor of the poor" (Pollard, 211).

\author{
There's blood on your new foreign shrubs, squire; \\ There's blood on your pointer's feet; \\ There's blood on the game you sell, squire, \\ And there's blood on the game you eat! \\ You have sold the labouring man, squire, \\ Body and soul to shame, \\ To pay for your seat in the House, squire, \\ And to pay for the feed of your game.
}

We quarrelled like brutes, and who wonders?

What self-respect could we keep,

Worse housed than your hacks and your pointers,

Worse fed than your hogs and your sheep?

Our daughters with base-born babies

Have wandered away in their shame;

If your misses had slept, squire, where they did,

Your misses might do the same. (Yeast, 147-8)

Kingsley's direct over-explicit attack, and the social attitude implied in the book, as Arnold Kettle writes, gave it "its notoriety and led a number of the readers of Fraser's Magazine to threaten to withdraw their subscriptions" (Kettle 1834), therefore the story was cut short by Fraser's because it was feared that the serial was injuring the sale of the magazine.

In his portrait of "The Village Revel", and in his exposure throughout the book of permanent deep social evils, Kingsley wanted to "shatter the notion that dirt and disease existed only in industrial towns, and that life in the country was healthy and idyllic" (Pollard, 210). It is among the taunted and the degraded poor of the village that we see Mary, a "coarse, handsome" and "showily-dressed girl" (Yeast, 181), who tries desperately and intently to discover where she can find the man who has ruined her? Mary follows the traditional way to prostitution. From her brief interview with the gamekeeper and Lancelot, it becomes apparent that she has been seduced by a man above her in station, and went on the street after his desertion of her. It is through her that Kingsley shows the sexual exploitation to which such girls were subjected, and makes his attack on the hypocrisy and the moral dissolution of upper-class gentlemen:

Curse you gentlemen all! Cowards! You are all in a league against us poor girls! You can hunt alone when you betray us, and lie fast enough then? But when we come for justice, you all herd together like a flock of rooks; and turn so delicate and honourable all of a sudden-to each other .... tell him you saw me; tell him you saw Mary; tell him where and in what a pretty place, too, for maid, master, or man! (Yeast,181).

Colonel Bracebridge, the seducer, is introduced as a fox hunter and a courteous gentleman of "long practice and consummate skill in all he took in hand", with "experience of all society, from the prairie Indian to Crockford's, from the prize-ring to the continental courts" (Yeast, 9). After seducing the country girl, he abandons her to her fate and devotes himself to the joyful pursuit of sport, fox-hunting, and touring the continent.

In his treatment of the Mary's miserable case, Kingsley's swerves from the established literary conventions of the period. He does not show her as responsible for her fall, nor does he let her alone bear its consequences. It is a common responsibility for both the seduced and the seducer. Mary does not accept her condition meekly and pine away, as other Victorian characters in the literature of that decade would do under similar circumstances, for sin. Her letter to her seducer does not contain the traditional meek admission of sin and horror-stricken feelings of guilt, nor a sentimental yearning for repentance, but rather spiteful language and an eloquent accusation of moral depravity and dishonesty. Unlike Henry Carpenter, who walks free from his crime, the news of the death of his child and the imprisonment of the mother is shown to have filled the seducer Colonel Bracebridge with feelings of shame and guilt and turned him into a 
"haggard and life-weary" figure murmuring incoherently from time to time "my own child! And I never shall have another" (Yeast, 231). The arrival of the letter which tells of the misery and horror of his deed drives him finally to take his own life.

The exaggerated reactions of both Mary and Colonel Bracebridge spoil the desired moral message and fail to sustain the reader's sympathy. Mary's anger is carried too far. Her vengeance is contrary to any maternal feelings, and the killing of her baby uproots our initial pity. Colonel Bracebridge's alleged "suicide" has struck readers like Baldwin Stanley as a "farce" (Stanley, 88). We cannot conceive of such a character committing suicide because of the wronged girl's passionate letter: "How I loved you once! How I hate you now! But I have my revenge. Your baby cried twice after it was born" (Yeast, 233). In exaggerating the seducer's feelings of shame and conscience-smitten reaction "the social novelist", according to Stanley, has "become the writer of melodramatic comedy" (88).

Kingsley's break from the literary conventions of his time is not total. The story closes with no hint of a possible reconciliation or a return to respectable society. It is not known what becomes of this los soul, yet from Bracebridge's explicit admission that there is "no second chance for those who---" (Yeast, 231-2) we can guess at her future.

In AIton Locke, Kingsley's interest in the condition of women moves from the agricultural workers and their sufferings to the problem of the urban poor in London. The book sheds light on social and moral issues than economic ones, and follows Carlyle's sartorial metaphors in Sartos Resartus, and turns Alton Locke into an allegory about the condition of the poor class. He was well aware of working-class radicalism and was very concerned about its possible outcome. His acquaintance with Maurice, Ludlow and others who dealt with the miserable conditions of sweatshops kindled his interest in the subject. Following up Ludlow's investigations into the lives of dress-makers and tailors, he wrote for Fraser's Magazine a fervid article "Cheap Clothes and Nasty" which formed the germ of this book.

The sewing profesion was one of the few fields open to women of the 1840s. Long hours of work for meagre reward made many seamstresses accept prostitution as inescapable and gave the trade a notorious reputation ${ }^{1}$. In this novel also, Kingsley utilizes "the fallen woman" to describe the brutal working conditions, of slopworkers:

Up stair after stair we went, while wails of children and curses of men, steamed out upon the hot stifling rush of air from every doorway, till at the topmost story we knocked at a garret door. We entered. Bare it was of furniture, comfortless, and freezing cold .... upon a few rags on the floor lay a girl, ugly, small-pox marked, hollow-eyed, emaciated, her only bed-clothes the skirt of a large handsome new riding-habit, at which two other girls, wan and tawdry, were stitching busily, as they sat right and left of her on the floor (Alton Locke, 95-6).

He makes it clear that low wages and sheer economic need are the primary causes that push these poor girls to the street:

We only earned three shillings a week, and there was ever so much to take off for fire, and two pence for thread, and five pence for candles; and then we were always getting fined, because they never gave us out the work till too late on purpose, and then lowered prices again; and now Ellen can't work at all, and there's four of us with the old lady, to keep off two's work that couldn't keep themselves alone (Alton Locke, 98).

Since the novel was written to criticize the economic system, Kingsley does not hesitate to replace the romantic motive by a practical one. The unfortunate lost souls that he introduces are purely economic victims driven to the streets by want. He attacks the rich who "would not set" them in business, or "help them to emigrate, or lift them out of the gutter with a pair of tongs, for fear they should stain their own whitewash in handling them" (Alton Locke, 393), and shows by the example set by Lady Ellerton, who organizes fallen needlewomen into a craft cooperative, that as soon as they are given the opportunity to earn a decent Iiving, they immediately leave their miserable trade:

And sure they're as decent as myself ow,the poor darlints! It was misery ruv'em to it, every one; perhaps it might hav' druv me the same way if I'd a lot o' childrer (Alton Locke, 393-4).

Kinsley's implication that nearly every woman is capable of prostitution if pressed by economic need, his outspoken description of slum conditions, and his support for the Chartist demands shocked some of his contemporaries and the book "was refused by the editor, John Parker, as being too dangerous" (Huxley, 40). Yet, despite the "sneers and abuse, there were many thoughtful men who considered it one of the finest pieces of work that Kingsley had done" (Stanley). Thomas Carlyle called the book "a salvo of red-hot shot against the Devil's Dungheap" (Kingsley, 92), and gave him an "introduction to Messrs Chapman and Hall, who, on his recommendation, undertook to bring it out," (Kingsley, 92).

To a great extent, Alton Locke can be considered as a fictionalized version of the reports of Mayhew and other social writers of the period about some of the fundamental problems of the working classes of the 1840s. John Bradley believes that Mayhew's writings made a profound mark upon the sociological novelists and that this is 
especially apparent in two works by Charles Kingsley: his pamphlet 'Cheap Clothes and Nasty' and his novel. Alton Locke. While the former is little more than a series of acknowledged excerpts from Mayhew's Chronicle articles, the latter looks to them for urban description, for means of advancing the narrative and for certain specific incidents (Bradley, xxxv).

In proving his point, Bradley shows the similarities between Kingsley's description of some scenes and those which Mayhew reported in his letters such as the comparison between the slum conditions at Bermondsey and Mayhew's report of the notorious Jacob Island (Bradley xxxvi), and between Mayhew's moving account of the needle woman forced into prostitution and Kingsley's description of Lizzy and her friend (Bradley, xxxviii).

As in Yeast, Kingsley here deals with the problem of these degraded lost souls with little psychological depth. While in Yeast, he gets rid of the baby, in Alton Locke he removes his source of complexity completely, and the seducer is not even mentioned. He uses these degraded and miserable figures for reform purposes. Like Thomas Hood in 'the Bridge of Sighs", Kingsley emphasizes that these sufferers are fellow humans, appeals to the reader for pity and tolerance, and attacks society's indifference. Hood skillfully uses suggestions and implications to avoid naming the profession of his "one more unfortunate", exactly in the same way as Kingsley does for his unfortunate heroines.

\section{Conclusion}

The impact of these novels on the readers, like Hood's poems, was immense--especially their appeal to Christian charity and human brotherhood. In chapter IX of Alton Locke, Kingsley asks: "Which of poor Hood's lyrics have an equal chance of immortality with "The Song of the Shirt" and "The Bridge of Sighs," rising, as they do, right out of the depths of the Inferno, sublime from their simplicity"? They stirred public interest in the subject, and in a time in which novels could bring tears to the eyes of strong men, novelists too found the theme attractive, yet at the same time difficult. Rigid and long-established attitudes towards the "unfortunate" woman restricted their freedom, and writers who were anxious not to lose the interest of the reading public realized that it would not be easy to write in opposition to the accepted standards of propriety and convention. The subject could be accepted if treated with reticence and within the limits of decorum as it is the case in Dickens's early novels. Even J.A. Froude who tried to invoke all possible extenuating circumstances in his sympathetic treatment of the subject in The Lieutenant's Daughter could not save his unfortunate heroine from her doomed death. This explains why Kingsley does not delve deep into her problems, nor does he try to imagine the possibility of tolerating her sin and bringing her to respectable society. He highlights her miserable conditions for the sake of raising his readers' pity, and he uses her as an instrument of bringing about social reform.

\section{References}

Bradley, J.L. (Ed). (1965). "Introduction" to Selections from London Labour and the London Poor. Oxford: OUP. Dexter, W. (Ed). (1938). The Letters of Charles Dickens. (vol.1). Bloomsbury: The Nonesuch Press.

Huxley, E. (1973). The Kingsleys: A Biographical Anthology .London: Allen and Unwin.

Kettle, A. (1982). "The Early Victorian Social-Problem Novel" in Boris F. (Ed.) The New Pelican Guide to English Literature: From Dickens to Hardy. London: Penguin Books.

Kingsley, Ch. (1881). Alton Locke: Tailor and Poet. London: Macmillan.

Kingsley, Ch. (1891). Yeast: A Problem. London: Macmillan.

Kingsley, F.E. (Eed). (1877). Charles Kingsley: His Letters and Memories of His Life. (2 vols). London: Henry S. King \& Co.

Kingsley, F.E. (Ed). (2011). Charles Kingsley, His Letters and Memories of His, Life. (Vol. 2). Cambridge: Cambridge University Press.

Martin, R.B. (1959). The Dust of Combat: A Life of Charles Kingsley. London: Faber and Faber.

Pollard, A. (Ed). (1970). The Victorians. (Vol. vi) History of Literature in the English Language. London: Barrie and Jenkins.

Stanley, B.E. (1934). Charles Kingsley. Cornell University Press.

\section{Notes}

1. While serving as editor of Bentley's Miscellany in1831, Dickens wrote to an unnamed author of a paper which had been delayed in publication: "Mr Bentley considers it too broad, although it does not strike me as so broad, as to render its insertion dangerous. The question is, whether you can so alter it, as to make the doubtful lady a manteau-maker and give the interview more of a "courting character". (Dexter 141). 